\title{
Enhancing the Efficiency of SnS Solar Cells bia Band-Offset Engineering with a Zinc Oxysulfide Buffer Layer
}

\section{Citation}

Sinsermsuksakul, Prasert, Katy Hartman, Sang Bok Kim, Jaeyeong Heo, Leizhi Sun, Helen Hejin Park, Rupak Chakraborty, Tonio Buonassisi and Roy G. Gordon. 2013. Enhancing the efficiency of $\mathrm{SnS}$ solar cells via band-offset engineering with a zinc oxysulfide buffer layer. Applied Physics Letters 102(5): 053901.

\section{Published Version}

doi:10.1063/1.4789855

\section{Permanent link}

http://nrs.harvard.edu/urn-3:HUL.InstRepos:10564511

\section{Terms of Use}

This article was downloaded from Harvard University's DASH repository, and is made available under the terms and conditions applicable to Open Access Policy Articles, as set forth at http:// nrs.harvard.edu/urn-3:HUL.InstRepos:dash.current.terms-of-use\#OAP

\section{Share Your Story}

The Harvard community has made this article openly available.

Please share how this access benefits you. Submit a story.

Accessibility 


\title{
Enhancing the Efficiency of SnS Solar Cells via Band-Offset Engineering with
}

\section{a Zinc Oxysulfide Buffer Layer}

Prasert Sinsermsuksakul, ${ }^{1}$ Katy Hartman, ${ }^{2}$ Sang Bok Kim, ${ }^{1}$ Jaeyeong Heo, ${ }^{1, a)}$ Leizhi Sun, ${ }^{1}$ Helen Hejin Park, ${ }^{1}$ Rupak Chakraborty, ${ }^{2}$ Tonio Buonassisi, ${ }^{2}$ and Roy G. Gordon ${ }^{1, b)}$

${ }^{1}$ Harvard University, Cambridge, Massachusetts 02138, USA

${ }^{2}$ Massachusetts Institute of Technology, Cambridge, Massachusetts 02139, USA

\begin{abstract}
$\underline{\text { Abstract }}$
$\mathrm{SnS}$ is a promising Earth-abundant material for photovoltaic applications. Heterojuction solar cells were made by vapor deposition of $p-$ type tin(II) sulfide, $\mathrm{SnS}$, and $n$-type zinc oxysulfide, $\mathrm{Zn}(\mathrm{O}, \mathrm{S})$, using a device structure of soda-lime glass/Mo/SnS/Zn(O,S)/ZnO/ITO. A record efficiency was achieved for SnS-based thin-film solar cells by varying the oxygen-tosulfur ratio in $\mathrm{Zn}(\mathrm{O}, \mathrm{S})$. Increasing the sulfur content in $\mathrm{Zn}(\mathrm{O}, \mathrm{S})$ raises the conduction band offset between $\mathrm{Zn}(\mathrm{O}, \mathrm{S})$ and $\mathrm{SnS}$ to an optimum slightly positive value. A record $\mathrm{SnS} / \mathrm{Zn}(\mathrm{O}, \mathrm{S})$ solar cell with a $\mathrm{S} / \mathrm{Zn}$ ratio of 0.37 exhibits short circuit current density $\left(J_{\mathrm{sc}}\right)$, open circuit voltage $\left(V_{\mathrm{oc}}\right)$ and fill factor $(\mathrm{FF})$ of $19.4 \mathrm{~mA} / \mathrm{cm}^{2}, 0.244 \mathrm{~V}$ and $42.97 \%$, respectively, as well as an NREL-certified total-area power-conversion efficiency of $2.04 \%$ and an uncertified active-area efficiency of $2.46 \%$.
\end{abstract}

\footnotetext{
${ }^{a}$ Curent address: Department of Material Science and Engineering, Chonnam National University, Gwangju 500757, South Korea.

b) Author to whom correspondence should be addressed. Electronic mail: gordon@chemistry.harvard.edu
} 
The toxicity of $\mathrm{Cd}$ and the scarcity of Te, In, and $\mathrm{Ga}$ used in $\mathrm{CdTe}$ and $\mathrm{Cu}(\mathrm{In}, \mathrm{Ga}) \mathrm{S}_{2}$ (CIGS) thin-film solar cells have motivated a search for alternative non-toxic, Earth-abundant, and inexpensive materials. ${ }^{1}$ Tin(II) sulfide $(\mathrm{SnS})$ is among the ongoing investigated materials such as $\mathrm{Cu}_{2} \mathrm{O},{ }^{2} \mathrm{Cu}_{2} \mathrm{~S},{ }^{3} \mathrm{FeS}_{2},{ }^{4,5} \mathrm{Cu}_{2} \mathrm{ZnSn}\left(\mathrm{S}_{x} \mathrm{Se}_{1-x}\right){ }_{4},{ }^{6}$ and $\mathrm{ZnSnP}_{2} .{ }^{7} \mathrm{SnS}$ has a suitable bandgap $\left(E_{\mathrm{g}}\right.$ $\sim 1.1-1.5 \mathrm{eV}),{ }^{8,9}$ strong optical absorption $\left(\alpha>10^{4} \mathrm{~cm}^{-1}\right),{ }^{10}$ and proper carrier concentration $\left([p] \sim 10^{14}-10^{17} \mathrm{~cm}^{-3}\right) .{ }^{11}$ Recently, a record efficiency SnS solar cell of $1.95 \%$ (active area) was fabricated from $p$ - $n$ homojunction nanowires using boron and phosphorus as dopants. ${ }^{12}$ In addition, SnS-based solar cells have been reported using different $n$-type partners such as $\mathrm{ZnO},{ }^{13}$ $\mathrm{CdS},{ }^{14,15} \mathrm{Cd}_{1-x} \mathrm{Zn}_{x} \mathrm{~S},{ }^{16} \mathrm{SnS}_{2},{ }^{17} \mathrm{TiO}_{2},{ }^{18}$ and $a-\mathrm{Si}^{19}$ So far, the best $\mathrm{SnS}$ planar heterojunction device was fabricated with $\mathrm{SnS} / \mathrm{CdS}$, achieving a power conversion efficiency $(\eta)$ of $1.3 \% .{ }^{14}$ The efficiencies achieved using heterojunctions of $\mathrm{SnS}$ with $n$-type materials other than $\mathrm{CdS}$ are extremely low $(<0.1 \%)$, mainly limited by low short-circuit current density $\left(J_{\mathrm{sc}}<1.5 \mathrm{~mA} / \mathrm{cm}^{2}\right)$. This poor $J_{\mathrm{sc}}$ is likely a result of bulk recombination in $\mathrm{SnS}$ because of defects, e.g., grain boundaries, intrinsic point defects such as sulfur vacancies, ${ }^{11}$ and/or impurities that arise from the preparation methods used to make the films.

In addition to the quality of $\mathrm{SnS}$, other main contributors to this poor efficiency are believed to be an unfavorable conduction-band offset (CBO) and rapid carrier recombination at trap states near the interface between $\mathrm{SnS}$ and the $n$-type buffer layer. $\mathrm{SnS} / \mathrm{CdS}$ forms a type-II heterojunction with the $\mathrm{CBO}\left(\Delta E_{\mathrm{c}}=\chi_{\mathrm{SnS}}-\chi_{\mathrm{CdS}}\right.$, where $\chi$ is electron affinity $)$ of $-0.4 \mathrm{eV}$, which is an unfavorable band alignment for making efficient solar cells. ${ }^{20}$ According to device simulations, a large negative $\mathrm{CBO}$ gives rise to an increase in the interface recombination, while a large positive $\mathrm{CBO}$ greater than $+0.5 \mathrm{eV}$ creates a barrier in the conduction band that impedes the collection of photo-generated electron..$^{21,22}$ Thus, a small positive CBO is desirable to reduce 
interface recombination without any loss in photo-current collection. ${ }^{21,22}$ One of the approaches to adjust the $\mathrm{CBO}$ is to vary the constituent elements in the semiconductor-alloy buffer layer. For example, $(\mathrm{Zn}, \mathrm{Cd}) \mathrm{S},{ }^{23}(\mathrm{Zn}, \mathrm{Mg}) \mathrm{O},{ }^{24}(\mathrm{Zn}, \mathrm{Sn}) \mathrm{O}_{\mathrm{x}},{ }^{25}$ and $\mathrm{Zn}(\mathrm{O}, \mathrm{S})^{26}$ were used in an attempt to replace CdS in CIGS solar cells. In this letter, we present a $\mathrm{SnS}$ device with a record power conversion efficiency of $2.04 \%$ (total area) using $\mathrm{Zn}(\mathrm{O}, \mathrm{S})$ as an $n$-type buffer layer, and evaluate the effect of $\mathrm{CBO}$ on device performance.

A device structure of soda-lime glass/Mo/SnS/Zn(O,S)/ZnO/ITO was used in this study. SnS thin films were deposited on Mo-coated $(450 \mathrm{~nm})$ soda-lime glass substrates using a pulsed chemical vapor deposition (pulsed-CVD) process from the reaction of $\operatorname{bis}\left(N, N^{\prime}\right.$ diisopropylacetamidinato)tin(II) $\left(\mathrm{Sn}\left(\mathrm{MeC}(\mathrm{N}-i \mathrm{Pr})_{2}\right)_{2}\right)$ and hydrogen sulfide $\left(\mathrm{H}_{2} \mathrm{~S}\right) .{ }^{27}$ The sequence of one cycle of a pulsed-CVD is composed of (i) injection of tin precursor vapor using $\mathrm{N}_{2}$ assistance, (ii) injection of $\mathrm{H}_{2} \mathrm{~S}$ gas to mix and react with the tin precursor vapor trapped inside the deposition zone for $1 \mathrm{~s}$, and (iii) evacuation of the gas mixture and by-products for $2 \mathrm{~s}$. Compared to a conventional atomic layer deposition (ALD) of $\mathrm{SnS},{ }^{27}$ the pulsed-CVD process omits some purge steps, thereby increasing the deposition rate by more than an order of magnitude at the cost of some non-uniformity in the film thickness along the length of the reactor. The purity and optoelectrical properties of the obtained $\mathrm{SnS}$ films are the same as those grown from the ALD process reported elsewhere. ${ }^{27}$ The substrate temperature was set to $200^{\circ} \mathrm{C}$. The tin precursor source was kept at $95^{\circ} \mathrm{C}$. A gas mixture of $4 \% \mathrm{H}_{2} \mathrm{~S}$ in $\mathrm{N}_{2}$ (Airgas Inc.) was used as the source of sulfur. $\mathrm{H}_{2} \mathrm{~S}$ is a toxic, corrosive, and flammable gas (lower flammable limit of $4 \%$ ). ${ }^{28}$ Thus, it should be handled with caution. An appropriate reactor design for $\mathrm{H}_{2} \mathrm{~S}$ compatibility can be found elsewhere. ${ }^{29}$ The partial pressures of tin precursor and $\mathrm{H}_{2} \mathrm{~S}$ after injecting into the deposition zone for each cycle are approximately 100 and 240 mTorr, respectively. $\mathrm{Zn}(\mathrm{O}, \mathrm{S})(25-$ 
$30 \mathrm{~nm})$ and $\mathrm{ZnO}(10 \mathrm{~nm})$ were prepared by ALD at $120^{\circ} \mathrm{C}$ from the reaction of diethylzinc $\left(\mathrm{Zn}\left(\mathrm{C}_{2} \mathrm{H}_{5}\right)_{2}\right)$ (Sigma-Aldrich) with deionized water $\left(\mathrm{H}_{2} \mathrm{O}\right)$ and hydrogen sulfide $\left(\mathrm{H}_{2} \mathrm{~S}\right)$. To ensure the quality of the interface, $\mathrm{Zn}(\mathrm{O}, \mathrm{S})$ and $\mathrm{ZnO}$ layers were deposited immediately after the growth of $\mathrm{SnS}$ absorber layers without breaking vacuum. Indium tin oxide (ITO) (200 nm) was deposited at room temperature by RF magnetron sputtering through a shadow mask to define the cell area $\left(0.031\right.$ or $\left.0.71 \mathrm{~cm}^{2}\right)$. Additional electron-beam evaporated $\mathrm{Al}(500 \mathrm{~nm})$ metal grids were used for the $0.71 \mathrm{~cm}^{2}$ devices to further reduce the series resistance.

Device morphology was characterized using field-emission scanning electron microscopy (FESEM, Zeiss, Ultra-55). Rutherford backscattering spectrometry (RBS, Ionex 1.7 MV Tandetron) was performed to determine the elemental composition of $\mathrm{Zn}(\mathrm{O}, \mathrm{S})$. The grain orientations of $\mathrm{SnS}$ films on Mo substrates were examined by X-ray diffraction (XRD, PANalytical X'Pert Pro) with $\mathrm{Cu} \mathrm{K} \alpha$ radiation $(\lambda=1.542 \AA)$ using $\theta-2 \theta$ scan. External quantum efficiency (EQE) measurements were made at room temperature, using a PV Measurements Model QEX7 tool. Transmittance $(T)$ and reflectance $(R)$ measurements were taken on a Hitachi U-4100 UV-Vis-NIR Spectrophotometer. Internal quantum efficiency (IQE) was calculated from $\mathrm{IQE}=\mathrm{EQE} /(1-R) . J-V$ measurements were made using a Keithley 2400 sourcemeter. The standard $1000 \mathrm{~W} / \mathrm{m}^{2}$ illumination was generated by a Newport Oriel 91194 solar simulator with a 1300 W Xe-lamp, an AM1.5G filter, and a Newport Oriel 68951 flux controller calibrated by an NREL-certified Si reference cell equipped with a BK-7 window. Suns $V_{\text {oc }}$ measurements were made using a Suns- $\mathrm{V}_{\mathrm{oc}}-150$ Illumination Voltage Tester from Sinton Consulting Inc. ${ }^{30}$

To determine the optimum composition of the $\mathrm{Zn}(\mathrm{O}, \mathrm{S})$ buffer layer for $\mathrm{SnS}$, small devices with an active area of $0.031 \mathrm{~cm}^{2}$ were fabricated using $500 \mathrm{~nm}$-thick $\mathrm{SnS}$ with $\mathrm{Zn}(\mathrm{O}, \mathrm{S})$ of different oxygen-to-sulfur ratios. By varying the cycle ratio of $\mathrm{ZnO}$ to $\mathrm{ZnS}$ during the ALD 
process, the elemental composition of $\mathrm{Zn}(\mathrm{O}, \mathrm{S})$ can be adjusted. ${ }^{31} \mathrm{ZnO}: \mathrm{ZnS}$ cycle ratios of 4:1, 5.5:1 (which alternates 5:1 and 6:1), 6:1, and 7:1, which correspond to $\mathrm{Zn}(\mathrm{O}, \mathrm{S})$ of $\mathrm{O}: \mathrm{S}: \mathrm{Zn}$ ratios $=0.42: 0.73: 1,0.56: 0.58: 1,0.64: 0.50: 1$, and $0.72: 0.37: 1$, respectively, were used to fabricate the devices. Figure 1 shows current density-voltage $(J-V)$ characteristics under dark and illumination $\left(\sim 10 \mathrm{~mW} / \mathrm{cm}^{2}\right)$ from a microscope halogen lamp (color temperature $\left.=3300 \mathrm{~K}\right)$. This illumination condition, although different from the AM1.5 solar spectrum, is sufficient to test for junction character. Measured $J-V$ characteristics suggest that for $\mathrm{S} / \mathrm{Zn}>\sim 0.6$, the $\mathrm{SnS} / \mathrm{Zn}(\mathrm{O}, \mathrm{S})$ junction exhibits type-I behavior with $\Delta E_{\mathrm{c}}>+0.5 \mathrm{eV}$, i.e., an energy barrier impedes photogenerated electron flow, resulting in a very low $J_{\mathrm{sc}}$. For $\mathrm{S} / \mathrm{Zn} \leq \sim 0.5$, the devices do not exhibit such a carrier collection problem and are thus believed to have $\Delta E_{\mathrm{c}}<+0.5 \mathrm{eV}$. This trend corresponds well with the reported conduction band position of $\mathrm{Zn}(\mathrm{O}, \mathrm{S})$, which is raised (lower $\chi$ ) when the sulfur concentration in the film increases. ${ }^{32}$

After the optimum oxygen-to-sulfur ratios were determined for the $\mathrm{Zn}(\mathrm{O}, \mathrm{S})$ buffer layer, larger-area devices (total area of $0.71 \mathrm{~cm}^{2}$ ) were fabricated using $1.5 \mu$ m-thick SnS absorber layers with $\mathrm{Zn}(\mathrm{O}, \mathrm{S})$ of $\mathrm{S} / \mathrm{Zn}=0.37$ and 0.50 . Figure 2 shows cross-sectional and plan-view SEM images of a device after $\mathrm{Zn}(\mathrm{O}, \mathrm{S}) / \mathrm{ZnO}$ deposition. The $\mathrm{SnS}$ surface was covered uniformly by the buffer layer even at 25-30 nm thickness because of the conformal coating by ALD. The SnS film is columnar and composed of platelet-shaped grains. The observed cross-sectional grain size of SnS can be different (arrows in Fig. 2(a)) depending on the cleaving direction with respect to these platelet grains. Figure 3(a) displays $J-V$ characteristics of these devices under dark and AM1.5 illumination. For $\mathrm{S} / \mathrm{Zn}=0.50$, the device shows $J_{\mathrm{sc}}=9.1 \mathrm{~mA} / \mathrm{cm}^{2}, V_{\mathrm{oc}}=0.28 \mathrm{~V}, \mathrm{FF}=$ $29.9 \%$, and $\eta=0.74 \%$. Surprisingly, unlike the $500 \mathrm{~nm}-\mathrm{SnS}$ device (Fig. 1), the junction in this thicker $\mathrm{SnS}$ solar cell shows some signs of a large positive CBO including a dark/light $J-V$ cross- 
over, higher diode voltage (i.e. $V_{\mathrm{oc}}$ ), small $\mathrm{FF}$, and low $J_{\mathrm{sc}}{ }^{33}$ This $\mathrm{CBO}$ discrepancy may be because of a variation of the $\mathrm{SnS}$ surface condition for different film thicknesses. Figure 3(b) shows the XRD spectra of SnS films grown on Mo layers as a function of SnS film thickness. The preferred crystal orientation of SnS film clearly shifts from (111) to (101) when the film thickness increases from 0.3 to $1.5 \mu \mathrm{m}$. Because of the anisotropic nature of the layered $\mathrm{SnS}$ compound, ${ }^{11,34}$ such a change in crystallographic orientation can strongly affect the surface conduction-band position of $\mathrm{SnS}$, and consequently its $\mathrm{CBO}$ with $\mathrm{Zn}(\mathrm{O}, \mathrm{S})$.

The internal quantum efficiency (IQE) (Fig. 3(c), solid line) of the $1.5 \mu$ m-thick SnS devices with $\mathrm{Zn}(\mathrm{O}, \mathrm{S})$ of $\mathrm{S} / \mathrm{Zn}=0.37$ and 0.50 shows three distinct regions of carrier collection. Above $800 \mathrm{~nm}$, the IQE is relatively low and limited by the low absorption coefficient and bulk recombination in SnS. The peaks of the IQE derivative (d(IQE)/dE) at 800 and $940 \mathrm{~nm}(1.55$ and $1.32 \mathrm{eV}$, respectively) correspond well to the sharp rise in absorption coefficient of $\mathrm{SnS}^{27}$ at these two wavelengths. Between 500 and $800 \mathrm{~nm}$, compared to the $\mathrm{S} / \mathrm{Zn}=0.37$ device, a significant drop in IQE of the $\mathrm{S} / \mathrm{Zn}=0.50$ device is observed because of the large positive $\mathrm{CBO}$. Below $500 \mathrm{~nm}$, the $\mathrm{S} / \mathrm{Zn}=0.50$ composition provides a better carrier collection despite having the large conduction-band energy barrier. This improved IQE at smaller wavelength can happen from photo-doping in the buffer layer, which results in a downward shift in the conduction band and thus reduces the $\mathrm{CBO}$ barrier. $^{35}$ In addition, $\mathrm{Zn}(\mathrm{O}, \mathrm{S})$ of $\mathrm{S} / \mathrm{Zn}=0.50$ also has a lower absorption tail as shown in Fig. 3(d) and thus exhibits a better blue response.

The $\mathrm{S} / \mathrm{Zn}=0.37$ device (Fig. 3(a)) exhibits the best performance with $J_{\mathrm{sc}}=16.8 \mathrm{~mA} / \mathrm{cm}^{2}$, $V_{\mathrm{oc}}=0.22 \mathrm{~V}, F F=47.7 \%$, and $\eta=1.8 \%$. The same device was characterized independently at the National Renewable Energy Laboratory (NREL), exhibiting an improved cell performance of $J_{\mathrm{sc}}=19.4 \mathrm{~mA} / \mathrm{cm}^{2}, V_{\mathrm{oc}}=0.244 \mathrm{~V}, F F=42.97 \%$, and $\eta=2.04 \%$, as shown in Fig. 4 . We suspect 
that the discrepancy between NREL and our in-house measurements arises from lower illumination of our solar simulator. This device shows the highest recorded and independently verified efficiency of a planar SnS-based solar cell to date. This result demonstrates the flexibility of $\mathrm{Zn}(\mathrm{O}, \mathrm{S})$ as an adjustable-CBO buffer layer for different surfaces or materials, which cannot be achieved in binary compounds (e.g., $\mathrm{CdS}, \mathrm{ZnO}, \mathrm{ZnS}, \mathrm{TiO}_{2}$, or $\mathrm{In}_{2} \mathrm{~S}_{3}$ ). The shortcircuit current density of $19.4 \mathrm{~mA} / \mathrm{cm}^{2}$ is significantly higher than all previously reported $\mathrm{SnS}$ solar cells $\left(9.6 \mathrm{~mA} / \mathrm{cm}^{2}\right)$. This result is probably because of a better interface junction with $\mathrm{Zn}(\mathrm{O}, \mathrm{S})$ and/or fewer defects in our SnS films, compared to other previously reported deposition techniques. The minority-carrier collection length (defined as depletion width + minority-carrier diffusion length) is roughly estimated from the IQE data of $\mathrm{S} / \mathrm{Zn}=0.37$ device fitted with a combined space-charge and minority-carrier diffusion length collection model (IQE $\cong 1$ $[\exp (-\alpha \times W)] /[\alpha \times L+1])$, where $\alpha$ is the optical absorption coefficient, $L$ is the minority-carrier diffusion length and $W$ is the width of the depletion region), primarily used for absorbers such as CIGS and CdTe. ${ }^{36}$ The fit suggests a minority-carrier collection length range of $0.2-0.4 \mu \mathrm{m}$. For further improvement, a heat treatment of $\mathrm{SnS}$ may be required to increase the grain size and reduce defects in the material.

It is worthwhile to note that additional improvements of FF can be made on current devices by optimizing the device structure alone; the Al metal grid used in these devices was too thin $(500 \mathrm{~nm})$, and the series resistance (estimated to be $6.0 \Omega \cdot \mathrm{cm}^{2}$ from fitted $J-V$ curves) notably reduced the FF of the device. Using Suns $\mathrm{V}_{\mathrm{oc}}{ }^{30,37}$ (data not shown), the FF without the effect of series resistance is estimated to be $60 \%$. This improvement in FF alone would yield a device with a pseudo-efficiency of $2.9 \%$. In addition, the metal contact grid also covered $17 \%$ of the total cell area and created a significant shadowing loss. Adjusting the NREL-certified 
efficiency for this shadowing loss, the active-area efficiency is estimated to be $2.46 \%$. The addition of an antireflection coating should help reduce the reflectance loss $(\sim 15 \%$ from reflectance measurements). Lastly, lock-in thermography images (not shown) indicate a noticeable leakage current around the perimeter of the device, a likely consequence of the lack of edge isolation.

In conclusion, a SnS-based device (total area of $0.71 \mathrm{~cm}^{2}$ ) comprising a $\mathrm{Zn}(\mathrm{O}, \mathrm{S})$ buffer layer achieved an NREL-certified full-area solar cell efficiency of $2.04 \%$, and an uncertified active-area efficiency of $2.46 \%$. The $\mathrm{SnS}$ absorber layer was deposited via pulsed-CVD, followed by ALD of the buffer layer without breaking vacuum. The optimum oxygen-to-sulfur ratio was found to vary depending on the absorber layer thickness (i.e., SnS preferred grain orientation), between $\mathrm{S} / \mathrm{Zn}=0.50$ and 0.37 for $500 \mathrm{~nm}$ and $1.5 \mu \mathrm{m}$, respectively. The versatility of $\mathrm{Zn}(\mathrm{O}, \mathrm{S})$ for $\mathrm{CBO}$ tuning was demonstrated, which could be utilized for a systematic study in other absorber materials as well. We expect that efficiencies can be further improved by optimizing contact geometry (shading losses, series resistance), adding an antireflection coating, improving bulk minority carrier diffusion length, reducing absorber thickness, and eliminating edge shunting; efficiencies can be improved by an order of magnitude or more, considering the Shockley-Queisser efficiency limit for $\mathrm{SnS}$ of $32 \%$.

\section{Acknowledgements}

We thank S. R. Kurtz, P. Ciszek, and the NREL cell measurement team for assistance with certified cell testing; J.T. Sullivan (MIT) with lock-in thermography measurements; J.T. Sullivan and R.E. Brandt (MIT) for helpful discussions; and M. Sher (Harvard University) with reflectivity measurements. The experimental contributions of Y. Segal in the early stages of this 
work are acknowledged. This work was supported by the U. S. National Science Foundation under NSF Award No. CBET-1032955, the U.S. Department of Energy SunShot Initiative under Contract No. DE-EE0005329, and by Saint Gobain S. A. which also supplied Mo-coated glass slides. P. Sinsermsuksakul acknowledges support from the Development and Promotion of Science and Technology Talents Project (DPST), Thailand. K. Hartman acknowledges the support of a National Science Foundation Graduate Research Fellowship. This work was performed in part at Harvard University's Center for Nanoscale Systems (CNS), a member of the National Nanotechnology Infrastructure Network (NNIN), which is supported by the National Science Foundation under NSF award No. ECS-0335765.

\section{Reference}

1 C. Wadia, A. P. Alivisatos, and D. M. Kammen, Environ. Sci. Technol. 43 (6), 20722077 (2009).

2 A. Mittiga, E. Salza, F. Sarto, M. Tucci, and R. Vasanthi, Appl. Phys. Lett. 88 (16), 163502 (2006).

3 Y. Wu, C. Wadia, W. L. Ma, B. Sadtler, and A. P. Alivisatos, Nano Lett. 8 (8), 25512555 (2008).

4 J. Puthussery, S. Seefeld, N. Berry M. Gibbs, and M. Law, J. Am. Chem. Soc. 133 (4), 716-719 (2011).

5 N. Berry, M. Cheng, C.L. Perkins, M. Limpinsel, J. C. Hemminger, and M. Law, Adv. Energy Mater. 2 (9), 1124-1135 (2012).

6 D. B. Mitzi, O. Gunawan, T. K. Todorov, K. Wang, and S. Guha, Sol. Energ. Mat. Sol. C 95 (6), 1421-1436 (2011).

7 D. O. Scanlon and A. Walsh, Appl. Phys. Lett. 100 (25), 251911 (2012).

8 K. Hartman, J. L. Johnson, M. I. Bertoni D. Recht, M. J. Aziz, M. A. Scarpulla, and T. Buonassisi, Thin Solid Films 519 (21), 7421-7424 (2011).

9 M. Devika, N. K. Reddy, K. Ramesh, R. Ganesan, K. R. Gunasekhar, E. S. R. Gopal, and K. T. R. Reddy, J. Electrochem. Soc. 154 (2), H67-H73 (2007).

10 N. K. Reddy, Y. B. Hahn, M. Devika, H. R. Sumana, and K. R. Gunasekhar, J. Appl. Phys. 101 (9), 093522 (2007).

11 J. Vidal, S. Lany, M. d'Avezac, A. Zunger, A. Zakutayev, J. Francis, and J. Tate, Appl. Phys. Lett. 100 (3), 032104 (2012).

12 G. Yue, Y. Lin, X. Wen, L. Wang, and D. Peng, J. Mater. Chem. 22 (32), 16437-16441 (2012).

13 B. Ghosh, M. Das, P. Banerjee, and S. Das, Semicond. Sci. Tech. 24 (2), 025024 (2009). 
K. T. R. Reddy, N. K. Reddy, and R. W. Miles, Sol. Energ. Mat. Sol. C 90 (18-19), 30413046 (2006).

S. A. Bashkirov, V. F. Gremenok, V. A. Ivanov, V. V. Lazenka, and K. Bente, Thin Solid Films 520 (17), 5807-5810 (2012).

M. Gunasekaran and M. Ichimura, Sol. Energ. Mat. Sol. C 91 (9), 774-778 (2007).

A. Sanchez-Juarez, A. Tiburcio-Silver, and A. Ortiz, Thin Solid Films 480, 452-456 (2005).

Y. Wang, H. Gong, B. H. Fan, and G. X. Hu, J. Phys. Chem. C 114 (7), 3256-3259 (2010).

F. Jiang, H. L. Shen, W. Wang, and L. Zhang, J. Electrochem. Soc. 159 (3), H235-H238 (2012).

M. Sugiyama, K. T. R. Reddy, N. Revathi, Y. Shimamoto, and Y. Murata, Thin Solid Films 519 (21), 7429-7431 (2011).

A. Niemegeers, M. Burgelman, and A. Devos, Appl. Phys. Lett. 67 (6), 843-845 (1995).

T. Minemoto, T. Matsui, H. Takakura, Y. Hamakawa, T. Negami, Y. Hashimoto, T.

Uenoyama, and M. Kitagawa, Sol. Energ. Mat. Sol. C 67 (1-4), 83-88 (2001).

B. Kumar, P. Vasekar, S. A. Pethe, N. G. Dhere, and G. I. Koishiyev, Thin Solid Films 517 (7), 2295-2299 (2009).

T. Minemoto, Y. Hashimoto, T. Satoh, T. Negami, H. Takakura, and Y. Hamakawa, J. Appl. Phys. 89 (12), 8327-8330 (2001).

M. Kapilashrami, C. X. Kronawitter, T. Torndahl, J. Lindahl, A. Hultqvist, W. C. Wang, C. L. Chang, S. S. Mao, and J. H. Guo, Phys. Chem. Chem. Phys. 14 (29), 10154-10159 (2012).

C. Platzer-Bjorkman, T. Torndahl, D. Abou-Ras, J. Malmstrom, J. Kessler, and L. Stolt, J. Appl. Phys. 100 (4), 044506 (2006).

P. Sinsermsuksakul, J. Heo, W. Noh, A. S. Hock, and R. G. Gordon, Adv. Energy Mater. 1 (6), 1116-1125 (2011).

Hydrogen Sulfide; MSDS No.001029; Airgas Inc.: Radnor, PA. April 26, (2010).

N. P. Dasgupta, J. F. Mack, M. C. Langston, A. Bousetta, and F. B. Prinz, Rev. Sci. Instrum. 81 (4), 044102 (2010).

R. A. Sinton and A. Cuevas, Proc. 16th European Photovoltaic Solar Energy Conf. 11521155 (UK, 2000).

B. W. Sanders and A. Kitai, Chem. Mater. 4 (5), 1005-1011 (1992).

C. Persson, C. Platzer-Bjorkman, J. Malmstrom, T. Torndahl, and M. Edoff, Phys. Rev. Lett. 97 (14), 146403 (2006).

A. O. Pudov, A. Kanevce, H. A. Al-Thani, J. R. Sites, and F. S. Hasoon, J. Appl. Phys. 97 (6), 064901 (2005).

W. Albers, H. J. Vink, C. Haas, and J. D. Wasscher, J. Appl. Phys. 32, 2220-2225 (1961). A. O. Pudov, J. R. Sites, M. A. Contreras, T. Nakada, and H. W. Schock, Thin Solid Films 480, 273-278 (2005).

S.S. Hegedus and W.N. Shafarman, Prog. Photovolt: Res. Appl. 12, 155-176 (2004).

M. J. Kerr and A. Cuevas, Sol. Energy 76 (1-3), 263-267 (2004). 


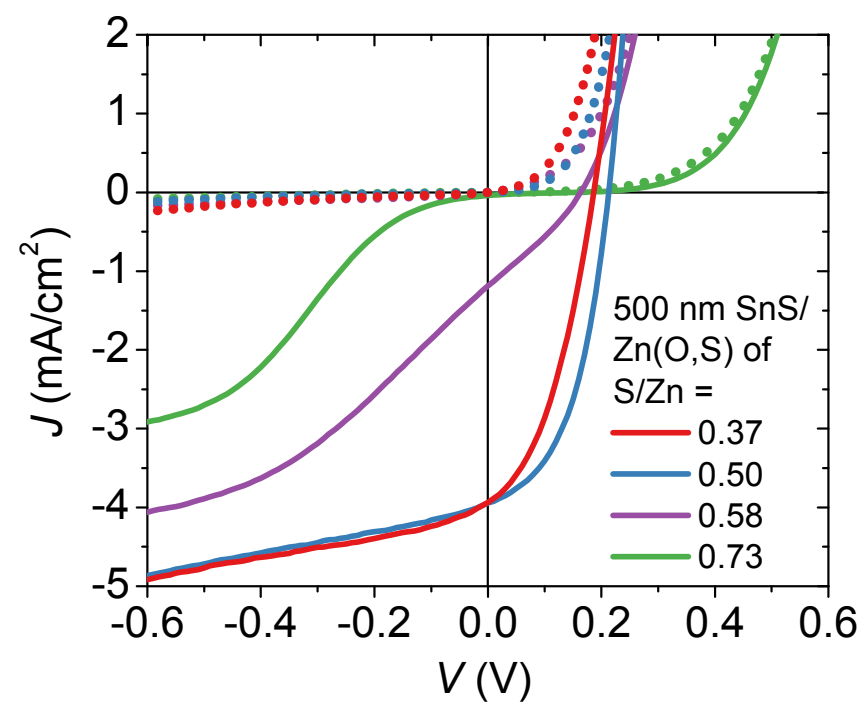

FIG. 1. Current density-voltage characteristics of $\mathrm{Mo} / 500 \mathrm{~nm}-\mathrm{SnS} / \mathrm{Zn}(\mathrm{O}, \mathrm{S}) / \mathrm{ZnO} / \mathrm{ITO}$ devices at different $\mathrm{Zn}(\mathrm{O}, \mathrm{S})$ compositions $(0.35<\mathrm{S} / \mathrm{Zn}<0.75)$ under dark (dotted line) and $\sim 10 \mathrm{~mW} / \mathrm{cm}^{2}$ illumination (solid line). 

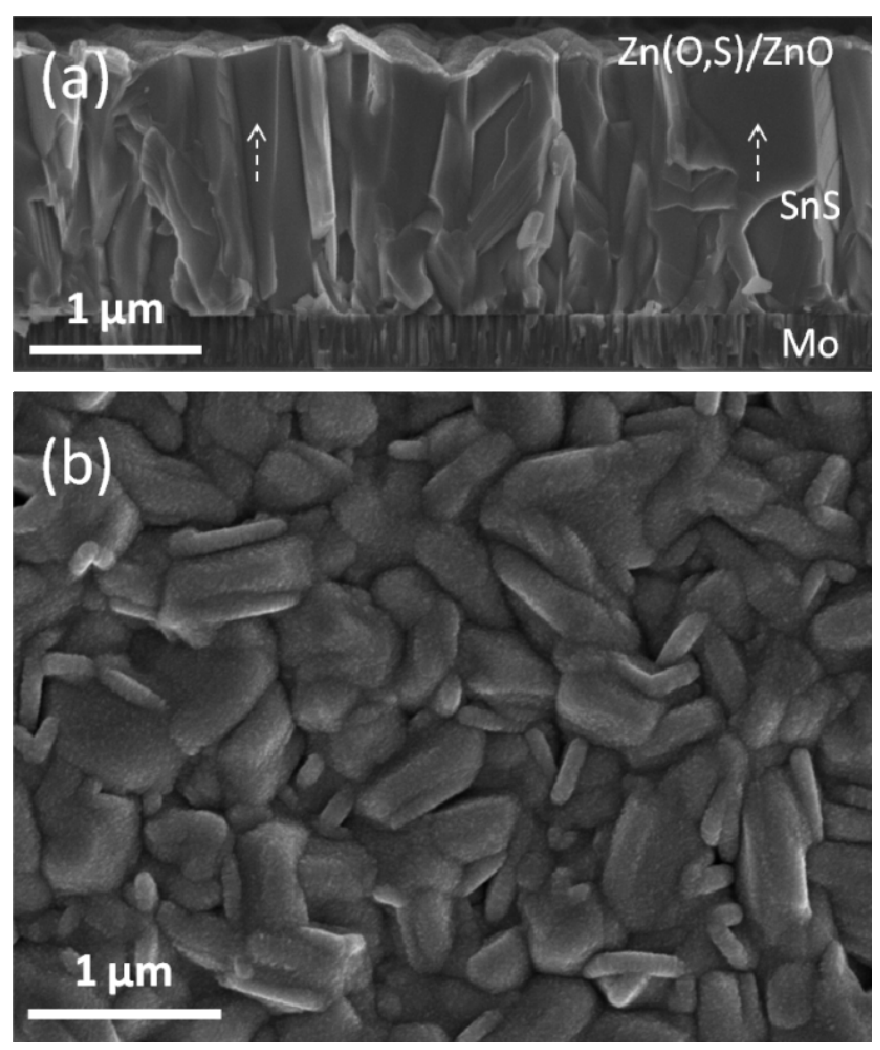

FIG. 2. SEM images of (a) cross-sectional and (b) plan-view of $\mathrm{Mo} / \mathrm{SnS} / \mathrm{Zn}(\mathrm{O}, \mathrm{S}) / \mathrm{ZnO}$ before top contact fabrication, showing a dense and conformal coverage of the $\mathrm{Zn}(\mathrm{O}, \mathrm{S})$ and $\mathrm{ZnO}$ layers grown via ALD. 

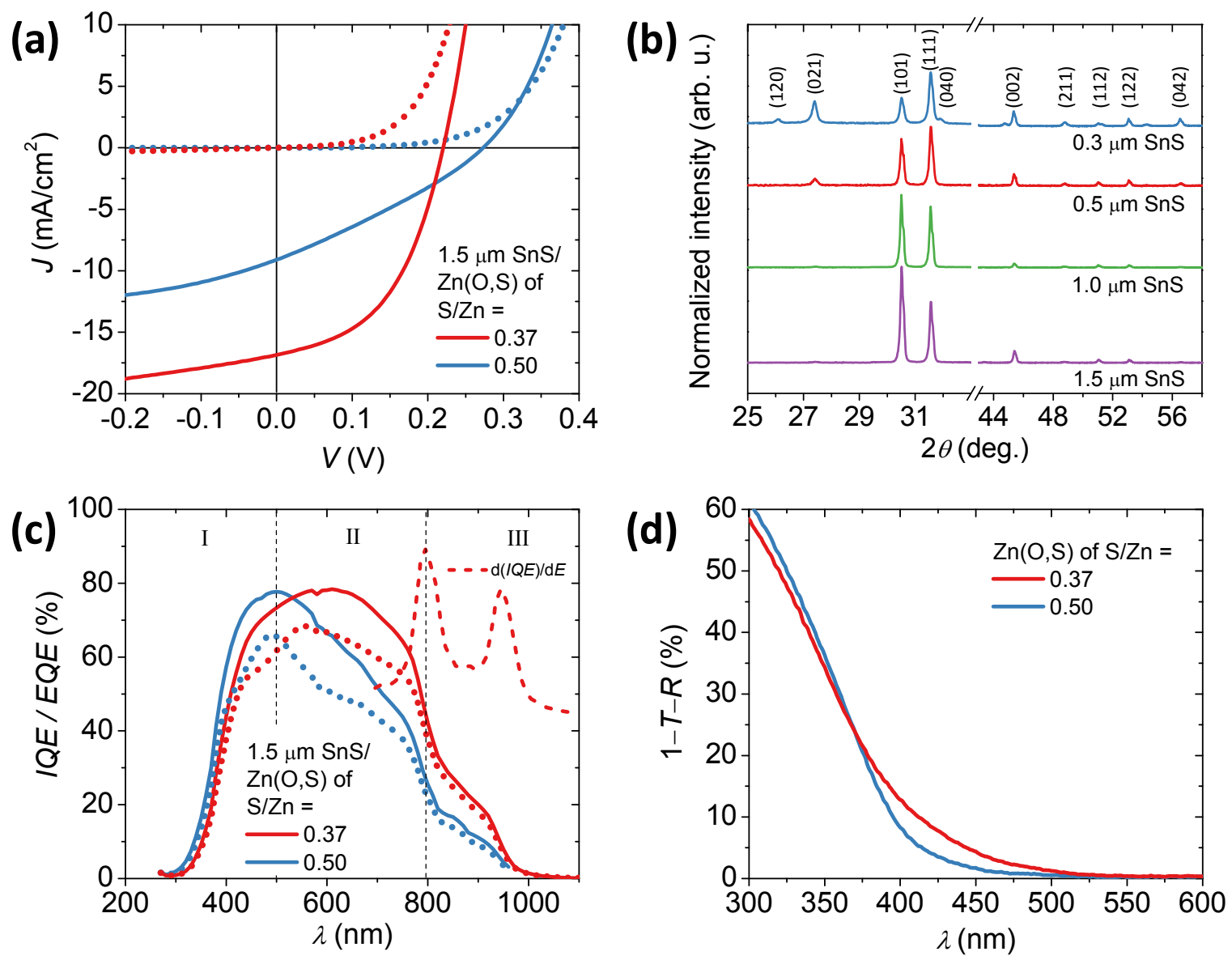

FIG. 3. (a) $J-V$ characteristic of $1.5 \mu \mathrm{m}$-thick $\mathrm{SnS}$ devices with $\mathrm{Zn}(\mathrm{O}, \mathrm{S})$ of $\mathrm{S} / \mathrm{Zn}=0.37$ and 0.50 under dark (dotted line) and approximately 1 sun illumination (solid line). (b) XRD spectra of $\mathrm{SnS}$ at the film thicknesses of $0.3,0.5,1.0$, and $1.5 \mu \mathrm{m}$. The intensity was normalized by the (111) peak. (c) IQE (solid line) and EQE (dotted line) of the same devices. The peaks of the IQE derivatives in the $\mathrm{S} / \mathrm{Zn}=0.37$ device correspond to the strong absorption edges of $\mathrm{SnS}$ at 1.32 and $1.55 \mathrm{eV}$. (d) Effective absorption (1-T-R) of $60 \mathrm{~nm}$-thick $\mathrm{Zn}(\mathrm{O}, \mathrm{S})$ of $\mathrm{S} / \mathrm{Zn}=0.37$ and 0.50 . 


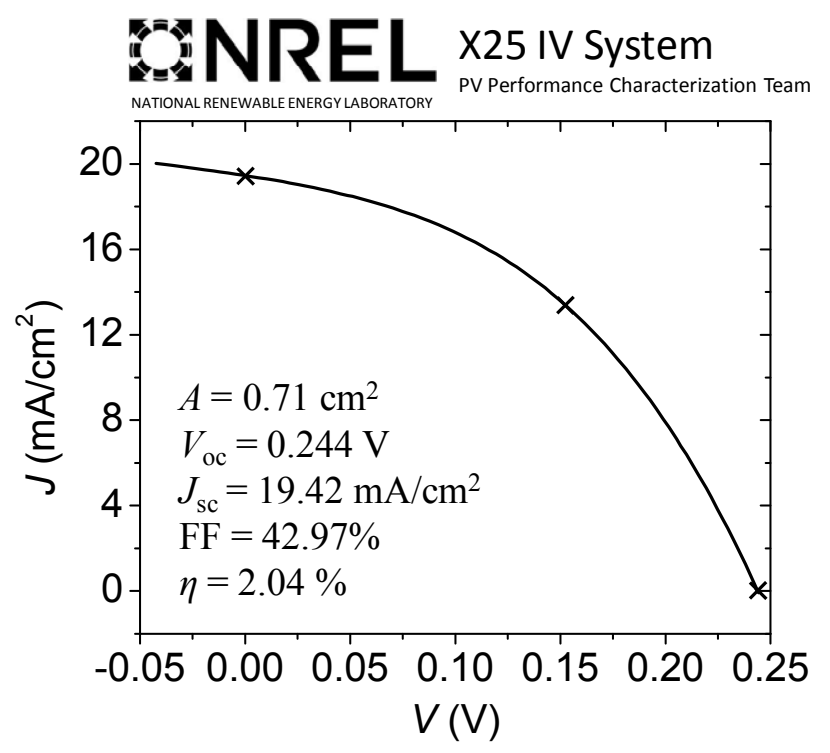

FIG. 4. A champion $\mathrm{SnS} / \mathrm{Zn}(\mathrm{O}, \mathrm{S})$ solar cell with a record efficiency of $2.04 \%$ (total area), as certified by NREL. 